\title{
The Zonal Structure of the Hadley Circulation
}

\author{
Peter G. BAINES*1,2 \\ ${ }^{1}$ Department of Civil and Environmental Engineering, University of Melbourne, Melbourne, Australia 3010 \\ ${ }^{2}$ Quantifying and Understanding the Earth System (QUEST), \\ Department of Earth Sciences, University of Bristol, Bristol BS8 1RJ, UK
}

(Received 3 April 2006; revised 9 August 2006)

\begin{abstract}
A discussion of the mass transport of the Hadley circulation is presented, with regard to its longitudinal structure. Data from the NCEP/NCAR reanalysis data set for the period 1948-2005 is examined, focusing on the solsticial seasons of June-August and December-February. Quantitative estimates have been extracted from the data to observe connections between the zonal mean of the upper tropospheric north/south mass transports and their relationship to the driving factor of tropical precipitation (implying latent heat release) and subsidence in the subtropical high pressure belts. The longitudinal structure of this flow is then examined with regard to these three main variables. The poleward upper tropospheric transport has four (JJA) or three (DJF) main branches, which link regions of major precipitation with corresponding regions of large subsidence, and one (June, July, August) or two (December, January, February) reverse branches. This structure has remained stable over the past sixty years. Although the total upper tropospheric transport in each season is less than the total sinking transport in the target subtropical high pressure belt, this does not apply to the individual branches, the balance being made up by the upper tropospheric reverse transports. An analysis of correlations between all of these various components shows, however, that the complete picture is more complex, with some precipitation regions being linked to subsidence regions outside their own branch.
\end{abstract}

Key words: Hadley circulation, precipitation, subsidence, horizontal and vertical transport

doi:

\section{Introduction}

A good understanding of the dynamics of climate depends on one's understanding of the atmospheric circulation. Confidence in the output of complex numerical models, in particular, depends on whether the model results are consistent with observations. In all of the literature on the atmospheric circulation there has been limited discussion of the three-dimensional pattern of flow, how this affects climate, and how well it is reproduced by models. Air parcel trajectories, for example, have received little attention. Perhaps the best coverage of the topic of mass, heat and energy and heat transport is that of Peixoto and Oort (1992) which, like most treatments, is mainly concerned with zonal averages. Here we are concerned with the mass flows of the Hadley circulation, and focus attention on its longitudinal three-dimensional structure in the tropical upper troposphere and the associated dynamical linkages.
There is some variation of what is meant by the term "Hadley circulation". For some, it means the zonal mean meridional tropical circulation, averaged over all longitudes. Here it is taken to mean the meridional circulation of the tropics with its full longitudinal structure, averaged over a period of time of at least a month, so that it is much longer than the synoptic time scale. In this paper, these periods are taken to be the seasons June-August and December-February. For these "solsticial" seasons, the mean for each constituent month is similar to the seasonal average, whereas in the "equinoctial" seasons of March-May and September-November the flows show monotonic change with time between the two solsticial states.

The advent of the National Centers for Environmental Prediction/National Center for Atmospheric Research (NCEP/NCAR) and European Centre for Medium-Range Weather Forecasts (ECMWF) global data sets in recent years has provided better and

*E-mail: p.baines@civenv.unimelb.edu.au 
more comprehensive descriptions of the circulation, and these data sets have been the basis of more precise studies than those possible previously (e.g., Trenberth and Stepaniak, 2003a, b). Recent dynamical studies have provided insights into mechanisms for the tropical circulation (Webster, 2004; Xie, 2004). The study described here examines 58 years of data from the NCEP/NCAR data set, which is regarded as "ruth" for present purposes. Comparisons made with data from ECMWF re-analyses show that these data give similar results for the tropical wind field (Trenberth et al., 2000; Baines and Folland, 2006). A description of the zonal mean tropical mass transport in the upper troposphere is presented in section 2. This is extended to a discussion in section 3 of the principal features of the longitudinal structure of this circulation, based on the time series of key variables. The conclusions are summarized in section 4.

\section{Variability of zonal mean transports in the tropics}

The atmospheric circulation in general, and the Hadley circulation in particular, are driven by the requirement to transfer heat from regions that are heated by the nett flux of radiation to those that have a nett deficit. For the seasons December-February (DJF) and June-August (JJA), this means from the summer side of the parallel at $15^{\circ}$ latitude in the winter hemisphere to the winter side of it. Figure 1 shows the conventional picture of the zonally averaged transport of mass in the atmosphere, for the annual means and the two solsticial seasons. The Hadley circulation is the flow between $30^{\circ} \mathrm{S}$ and $30^{\circ} \mathrm{N}$. The annual mean pattern is reasonably symmetrical, but there is a very large variation with the seasonal cycle. In the solsticial seasons DJF and JJA, the circulation is dominated by the cell on the winter hemisphere side, which has a transport of three times the annual mean; the summer cell almost disappears, and has a transport of about one third the annual mean. Figure 1 is based on data available in the $1980 \mathrm{~s}$, and it is useful to briefly reexamine the properties of this flow using re-analysis data to the present day.

The Hadley circulation is driven by latent heat release in the tropics of the summer hemisphere, and the magnitude of this heating is measured by the rainfall that reaches the ground. We here use this precipitation as a measure of the strength of the rising motion of the Hadley circulation. In order to look at the zonal mean picture and its variability, we consider inter-annual variations of this precipitation in regions north and south of the equator, the north-south transport in the upper troposphere associated with the

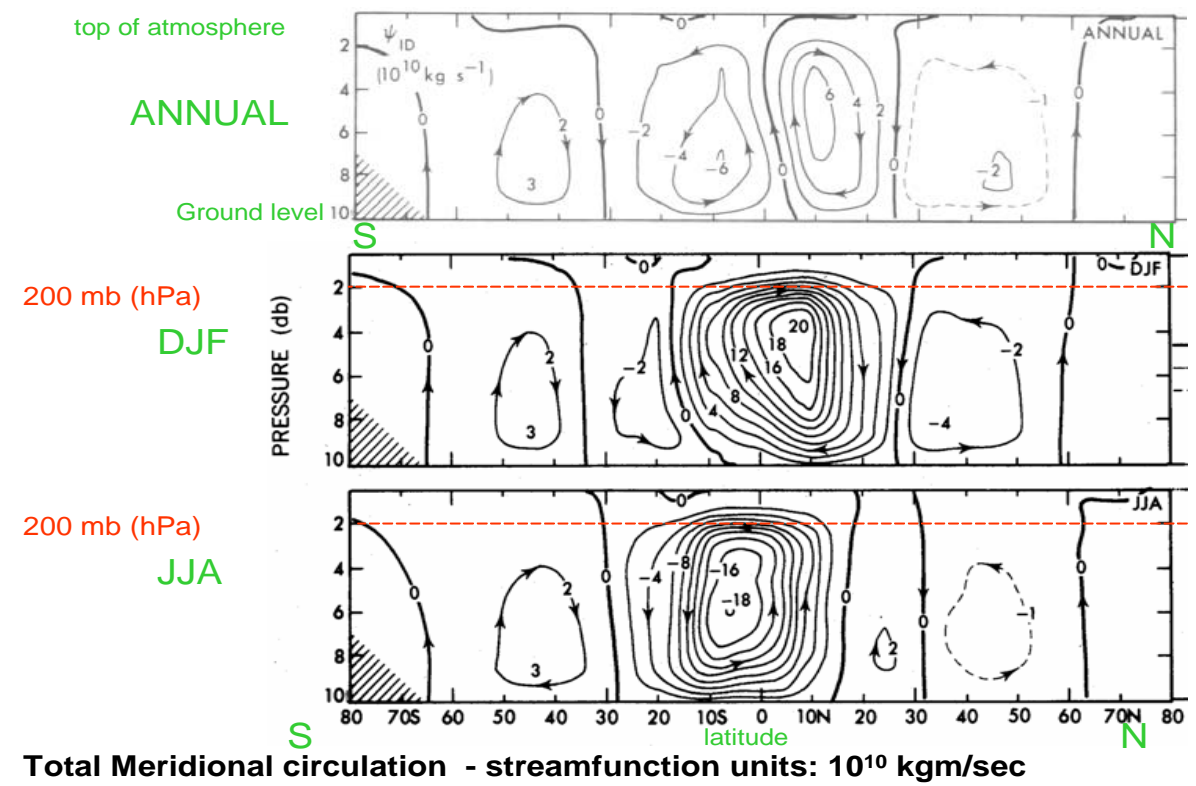

Fig. 1. The zonally averaged meridional circulation. Contours denote the meridional stream function in units of $10^{10} \mathrm{~kg} \mathrm{~m} \mathrm{~s}^{-1}$. The top frame denotes the annual mean, the middle frame the mean for the season December to February, and the bottom frame, for June to August. The Hadley circulation is the flow in the regions between $30^{\circ} \mathrm{S}$ and $30^{\circ} \mathrm{N}$. Note the large seasonal variation, and the dominance of the circulation cell of the winter hemisphere. Dashed lines denote the pressure level of $200 \mathrm{hPa}$, noted for future reference. Adapted from Peixoto and Oort (1992). 


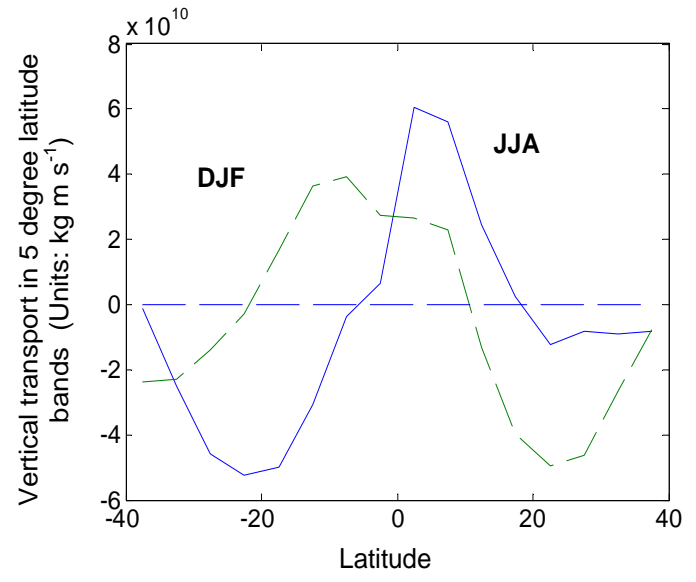

Fig. 2. Zonally averaged mean vertical mass transport at $500 \mathrm{hPa}$ for (a) June-August and (b) December-February from 1948-2006, from NCEP reanalysis. The ordinates are mass transport in $\mathrm{kg} \mathrm{m} \mathrm{s}^{-1}$ for 5 -degree bands of latitude, from $40^{\circ} \mathrm{S}$ to $40^{\circ} \mathrm{N}$.
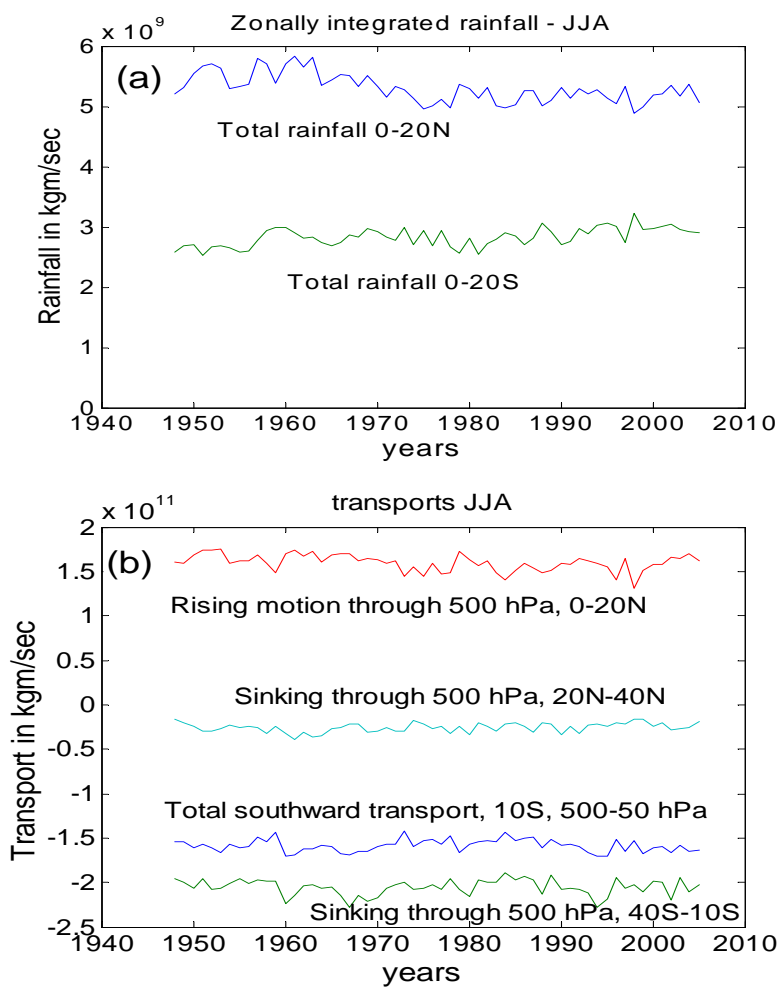

Fig. 3. (a) Mean precipitation rate over the latitude bands $0^{\circ}-20^{\circ} \mathrm{N}$ (blue) and $0^{\circ}-20^{\circ} \mathrm{S}$ (green) for the season JuneAugust for each year from 1948-2005, in $\mathrm{kg} \mathrm{m} \mathrm{s}^{-1}$. (b) Mean transport across $10^{\circ} \mathrm{S}$ in the pressure range $500 \mathrm{hPa}-$ $50 \mathrm{hPa}$ (the upper troposphere) - blue curve, and sinking across the pressure level $500 \mathrm{hPa}$ in the latitude bands $20^{\circ} \mathrm{N}-40^{\circ} \mathrm{N}$ (green curve) and $20^{\circ} \mathrm{S}-40^{\circ} \mathrm{S}$ (red curve). Negative values imply southward transport (blue) and downward transport (green, red). Data from NCEP/NCAR reanalysis.
Hadley circulation, and vertical transport through 500 $\mathrm{hPa}$, for the seasons JJA and DJF. Figure 2 shows the zonally integrated mean of the vertical mass transport at $500 \mathrm{hPa}$, from NCEP reanalysis, from 1948-2006, for JJA and DJF. On the basis of this figure, we divide the latitude range into regions in which the mass transport is mostly up or down, and look at the temporal variability of these area-averaged quantities. We consider six variables for each season. These are: the nett precipitation in the latitude bands $0-20^{\circ} \mathrm{N}$ and $0-20^{\circ} \mathrm{S}$ for both seasons, and for JJA, the nett northward transport in the upper troposphere (i.e. above $500 \mathrm{hPa}$ ) at $10^{\circ} \mathrm{S}$, and the vertical transport across the $500 \mathrm{hPa}$ level in the latitude bands $40^{\circ}-10^{\circ} \mathrm{S}, 0^{\circ}-20^{\circ} \mathrm{N}$, and $20^{\circ}-40^{\circ} \mathrm{N}$. The time series for these six variables are shown in Fig. 3. Each of them is seen to have a welldefined mean value over this period, and departures from it are not large relative to the mean. For JJA the rainfall in the north $\left(0^{\circ}-20^{\circ} \mathrm{N}\right)$ is approximately twice that in the south $\left(0^{\circ}-20^{\circ} \mathrm{S}\right)$, and the sinking in the south $\left(20^{\circ}-40^{\circ} \mathrm{S}\right)$ is much larger than that in the north $\left(20^{\circ}-40^{\circ} \mathrm{N}\right)$, which is consistent with expectations from Fig. 1. The extent to which these variables are related to each other in a mechanistic manner is shown by the correlations between them, and these are given in Table 1. The connections implicit in these correlations are depicted graphically in Fig. 4. These have some interesting implications, as follows. Without being too precise about questions of significance, with a record length of 58 years correlation coefficients with a magnitude above about 0.2 imply some connection between the variables, and particularly so for those above 0.3 . Firstly, there is a negative correlation between the rainfall north and south of the equator, so that a reduction in one implies a compensating increase in the other. The rainfall north of the equator, being much the larger of the two, is reassuringly strongly related to the rising motion in the same latitude band $\left(0^{\circ}-20^{\circ} \mathrm{N}\right)$. Both of these variables are also related to the northern subsidence, which may be identified as the weak northern cell of the Hadley circulation. The southward transport in the upper troposphere at $10^{\circ} \mathrm{S}$ is also strongly correlated with the sinking in the southern subsidence region, and the latter is large enough to swallow up the whole of this transport. This is consistent with the conventional picture of the Hadley circulation.

The correlations for the other extreme season, December-February, are shown in Table 2, and the graphs of the time series are shown in Fig. 5a. For DJF the section for northward transport is taken at $15^{\circ} \mathrm{N}$, with vertical transports in the ranges $40^{\circ}-20^{\circ} \mathrm{S}$, $20^{\circ}-15^{\circ} \mathrm{N}$, and $15^{\circ}-40^{\circ} \mathrm{N}$. The resulting schematic diagram of connections based on the correlations is shown 


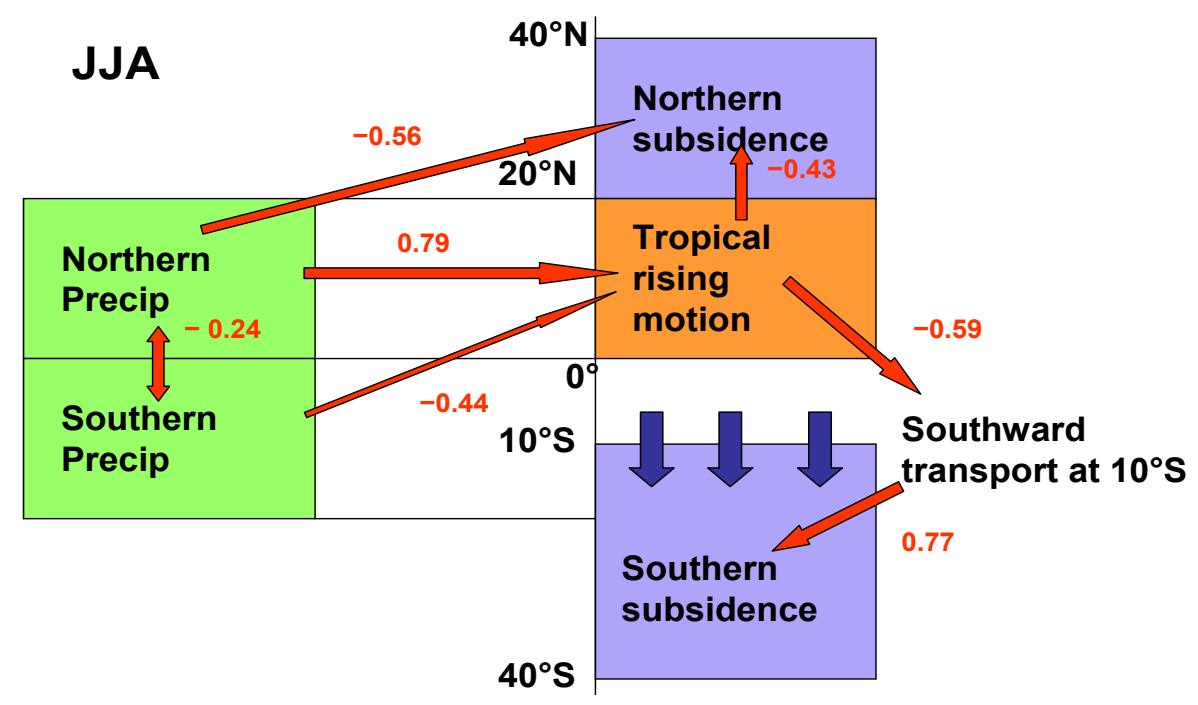

Fig. 4. Connections between the six zonal mean variables in Table 1 inferred from interannual correlations for the season June-August. All correlations with magnitude greater than 0.4 are shown, denoted by red arrows. The broad dark blue arrows denote the southward transport at $10^{\circ} \mathrm{S}$. For the signs of the correlations, the vertical transports are positive upward and north-south transport is positive northward.

Table 1. Correlation coefficients between the six zonally integrated variables for the season June-August shown in Fig. 4. PrecipN and PrecipS denote the precipitation rate in the latitude bands $0^{\circ}-20^{\circ} \mathrm{N}$ and $0-20^{\circ} \mathrm{S}$ respectively, Tr10S denotes the meridional mass transport across $10^{\circ} \mathrm{S}$ in the range $500-50 \mathrm{hPa}$, and Tw20-40N, Tw0-20N and Tw40S-10S denote the vertical mass transports across $500 \mathrm{hPa}$ in the latitude bands $20^{\circ}-40^{\circ} \mathrm{N}, 0^{\circ}-20^{\circ} \mathrm{N}$ and $40^{\circ}-10^{\circ} \mathrm{S}$ respectively. Correlation coefficients with magnitude above 0.7 are marked in red, others above 0.4 in green, and others above 0.2 in yellow. For the signs of the correlations, the vertical transports are positive upward and north-south transport is positive northward.

\begin{tabular}{l|r|r|r|r|r|r|} 
JJA & \multicolumn{1}{c}{ PrecipN } & \multicolumn{1}{c}{ Precips } & Tr1OS & TwO_2ON & Tw20N_40N & Tw40S_10S \\
\hline PrecipN & 1 & -0.2378 & -0.3395 & 0.7885 & -0.5647 & -0.2411 \\
Precips & -0.2378 & 1 & -0.0971 & -0.4373 & 0.0742 & -0.3138 \\
Tr10S & -0.3395 & -0.0971 & 1 & -0.5949 & 0.0643 & 0.7717 \\
TwO_2ON & 0.7885 & -0.4373 & -0.5949 & 1 & -0.4304 & -0.361 \\
\hline Tw2ON_4ON & -0.5647 & 0.0742 & 0.0643 & -0.4304 & 1 & 0.1558 \\
Tw40S_1OS & -0.2411 & -0.3138 & 0.7717 & -0.361 & 0.1558 & 1
\end{tabular}

Table 2. As for Table 1, except that the season is December-February, and the meridional mass transport $\operatorname{Tr} 15 \mathrm{~N}$ above $500 \mathrm{hPa}$ is across $15^{\circ} \mathrm{N}$.

\begin{tabular}{lrrrrrrr} 
DJF & \multicolumn{1}{c}{ PrecipN } & \multicolumn{1}{c}{ Precips } & Tr15N & Tw20S_10N & Tw15N_40N & Tw40S_20S \\
PrecipN & 1 & -0.6132 & -0.0871 & -0.5136 & -0.0259 & 0.0181 \\
Precips & -0.6132 & 1 & 0.4157 & 0.7554 & -0.2835 & 0.1516 \\
Tr15N & -0.0871 & 0.4157 & 1 & 0.7265 & -0.9247 & -0.0192 \\
Tw20S_1ON & -0.5136 & 0.7554 & 0.7265 & 1 & -0.6313 & 0.0102 \\
Tw15N_4ON & -0.0259 & -0.2835 & -0.9247 & -0.6313 & 1 & -0.0247 \\
Tw40S_2OS & 0.0181 & 0.1516 & -0.0192 & 0.0102 & -0.0247 & 1
\end{tabular}



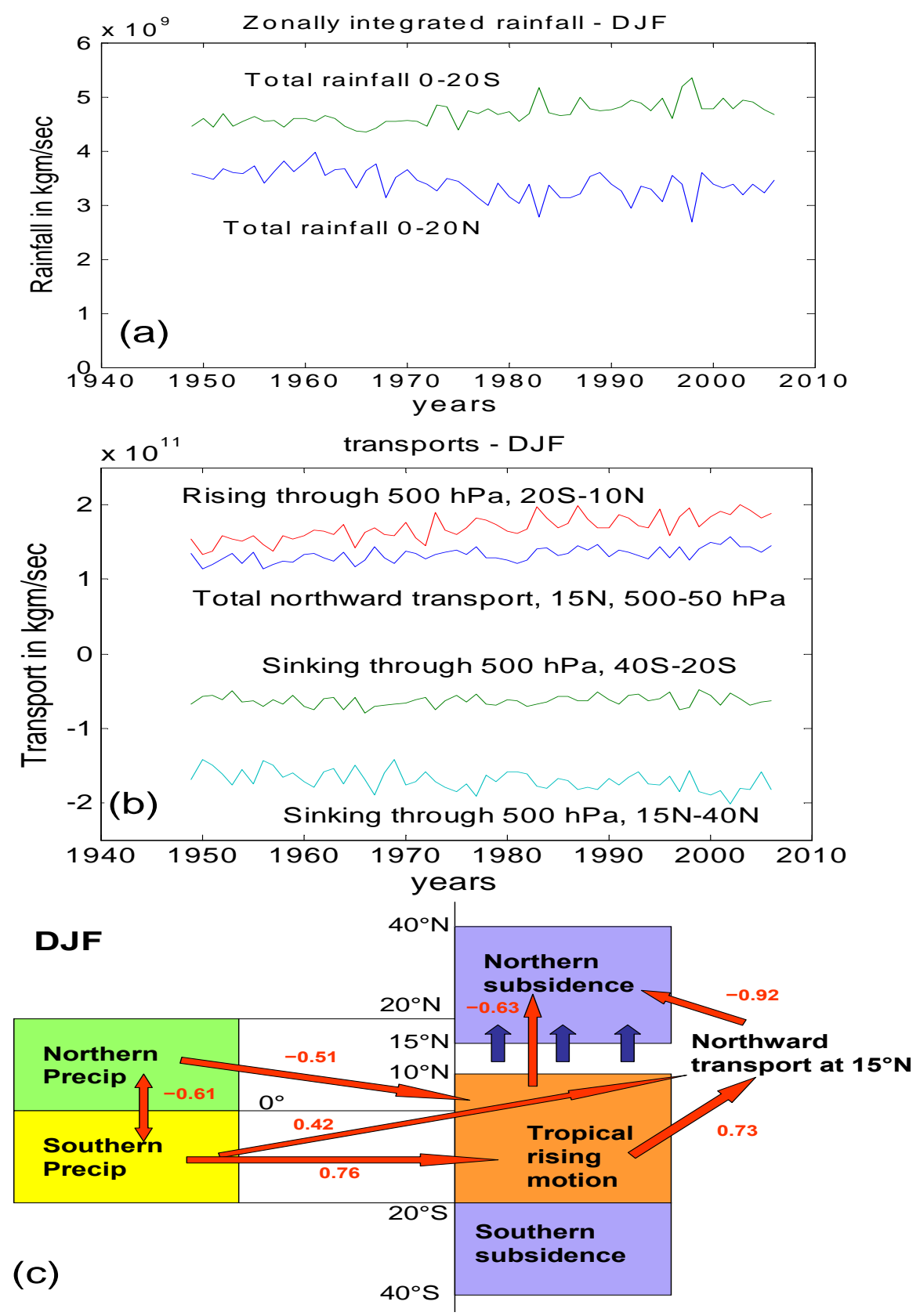

Fig. 5. As for Fig. 3 and 4, but for the season December-February. The broad blue arrows denote the northward transport at $15^{\circ} \mathrm{N}$.

in Fig. 5b. Many of the same features are evident with the hemispheres reversed: there is compensation between rainfall north and south of the equator, the subsidence between $15^{\circ} \mathrm{N}$ and $40^{\circ} \mathrm{N}$ exceeds the northward transport at $15^{\circ} \mathrm{N}$, and the variations are generally consistent with variations in the overturning of the dominant cell in the summer hemisphere. Interestingly though, in both seasons variations in the precipitation variables are weakly linked to the subsidence in either hemisphere except for the northern region in JJA.
The above details are broadly consistent with the familiar picture of the Hadley circulation as shown in Fig. 1. However, it is clear that this type of analysis leaves many unanswered questions. In particular, how can a flow such as depicted in Fig. 1 facilitate the transport of heat from the summer hemisphere to the winter one? On fluid dynamical grounds, a zonally symmetric convection cell as depicted would be expected to act as a barrier to heat transport across it. Clearly, the essential details that circumvent this 

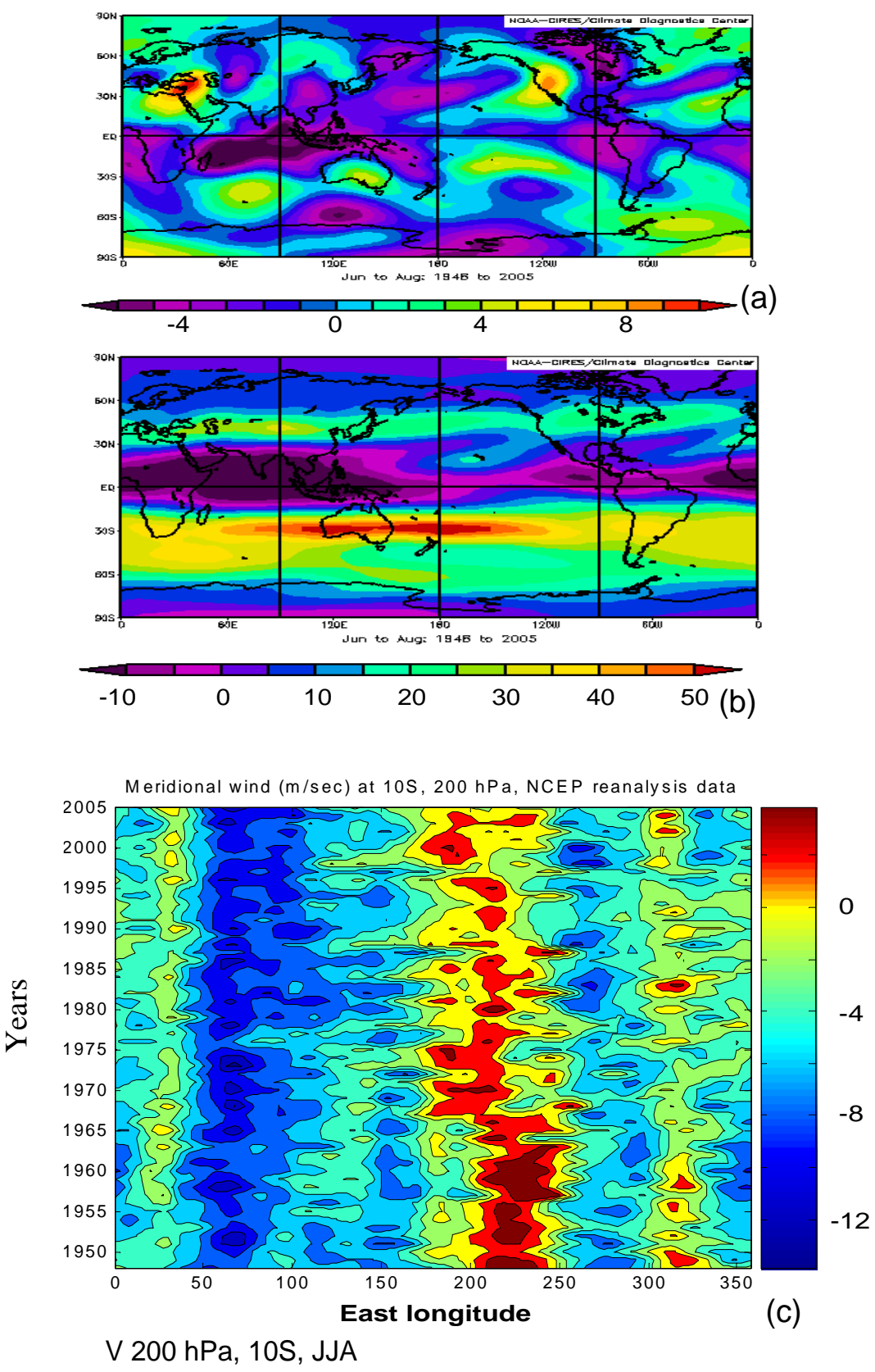

Fig. 6. The wind field at $200 \mathrm{hPa}$ for June-August. Velocities are in $\mathrm{m} \mathrm{s}^{-1}$. (a) Mean meridional wind for June-August over the period 1948-2005. (b) Mean zonal wind for June-August for 1948-2005. (c) Time series of the meridional wind at 200 $\mathrm{hPa}$ at $10^{\circ} \mathrm{S}$ for June-August. Data from NCEP/NCAR reanalysis.

must lie in the zonal variability of the Hadley circulation, which is the subject of the remainder of this paper.

\section{Zonal variations in transports in the tropics and sub-tropics}

The present day picture of the Hadley circulation involves the trade winds converging toward low lat- itudes over very long fetches over increasingly warm oceans, thereby acquiring progressively more moisture and latent energy. This process occurs in the each of the Pacific, Indian and Atlantic Oceans. In both the Indian and Atlantic Oceans in JJA, the southern trades cross the equator, lengthening the fetch over warmer water. This process ends in relatively localized regions of concentrated precipitation such as the 
Indian and African monsoon regions, where the latent energy released is primarily responsible for driving the upper level transport. The longitudinal structure of the Hadley circulation may be seen from the upper tropospheric wind field, represented by wind at 200 hPa. Figure 6 a shows the mean meridional wind from 1948-2005 for the season June-August at $200 \mathrm{hPa}$, and the corresponding zonal wind is shown in Fig. 6b. The southward motion of the upper branch of the Hadley circulation is seen to exist in four distinct branches, with an upper level return branch over the central Pacific Ocean. The southern subtropical jet stream at $30^{\circ} \mathrm{S}$ is prominent in Fig. 6b. It circles the globe, but is strongest in the sector between $60^{\circ} \mathrm{E}$ and $120^{\circ} \mathrm{W}$ longitude. The region where it increases in strength corresponds with the southward motion in Fig. 6a emanating from Africa and the Indian monsoon. In the central Pacific its velocity decrease is associated with divergence feeding the reverse Hadley circulation to the north, and southward motion to the south. Similar behaviour may be seen in the mid-latitude jet stream in the northern hemisphere, which has two growth and two divergence regions. Figure $6 \mathrm{c}$ shows the time series of the north-south flow at $10^{\circ} \mathrm{S}$. Considerable interannual variability is evident, but this figure shows that otherwise these branches of the Hadley circulation have been reasonably stable over the whole period of the reanalysis.
The locations of these branches are loosely associated with the regions of strong precipitation in the tropics. This is seen in Fig. 7, where Figure 7a shows the mean precipitation rate in the tropics for the whole period, and Fig. 7b the mean north/south transport at $10^{\circ} \mathrm{S}$. Comparing Fig. $7 \mathrm{a}$ with Fig. $6 \mathrm{a}$ and $7 \mathrm{~b}$, one sees that there is a general correspondence between the regions of large precipitation and large southward velocity in the upper troposphere. The third variable, shown in Fig. 7c, is the vertical motion at 500 $\mathrm{hPa}$. This shows the descent associated with subsidence in the semi-permanent highs (not shown) of the mid-latitude high pressure belt near $30^{\circ} \mathrm{N}$ and $30^{\circ} \mathrm{S}$, associated with the descending branch of the Hadley circulation. Time series of these variables have been extracted from the NCEP data set, in the form of integrals of them over each one of the white boxes in Fig. 7. The means and standard deviations of these quantities are given in Table 3, where the entries have been arranged to give columns that correspond in longitude as much as possible. One notes that the mean values in the second column for all four variables are noticeably larger than the others. In other words, the large precipitation associated with the Indian monsoon and over Southeast Asia (Pr2N) is apparently the cause of the large southward transport in the upper troposphere at $10^{\circ} \mathrm{S}$ in the longitude range $60^{\circ}-150^{\circ} \mathrm{E}(\operatorname{Tr} 2)$,

Table 3. Mean and standard deviations of the integrated quantities over the boxes in Fig. 9, marked by symbols and longitudes. The precipitation rate is in units of $10^{8} \mathrm{~kg} \mathrm{~m} \mathrm{~s}{ }^{-1}$ of water; the meridional and vertical mass transports are in units of $10^{10} \mathrm{~kg} \mathrm{~m} \mathrm{~s}{ }^{-1}$. Negative values imply southward meridional transports, or downward vertical transports. The columns are aligned to give the best correspondence in longitude ranges.

\begin{tabular}{|c|c|c|c|c|c|}
\hline & \multicolumn{5}{|c|}{ Precipitation $\left(0^{\circ}-20^{\circ} \mathrm{N}, 10^{8} \mathrm{~kg} \mathrm{~m} \mathrm{~s}{ }^{-1}\right)$} \\
\hline & $\operatorname{Pr} 1 \mathrm{~N}\left(20^{\circ} \mathrm{W}-30^{\circ} \mathrm{E}\right)$ & $\operatorname{Pr} 2 \mathrm{~N}\left(60^{\circ}-120^{\circ} \mathrm{E}\right)$ & $\operatorname{Pr} 3 \mathrm{~N}\left(135^{\circ}-180^{\circ} \mathrm{E}\right)$ & $\operatorname{Pr} 4 \mathrm{~N}\left(110^{\circ}-60^{\circ} \mathrm{W}\right)$ & \\
\hline Mean & 5.15 & 12.29 & 9.16 & 9.16 & \\
\hline \multirow[t]{3}{*}{ Standard } & 1.05 & 0.629 & 0.836 & 0.567 & \\
\hline & \multicolumn{5}{|c|}{ Precipitation $\left(0^{\circ}-20^{\circ} \mathrm{S}, 10^{8} \mathrm{~kg} \mathrm{~m} \mathrm{~s}{ }^{-1}\right)$} \\
\hline & \multicolumn{2}{|r|}{$\operatorname{Pr} 1 \mathrm{~S}\left(50^{\circ}-100^{\circ} \mathrm{E}\right)$} & \multicolumn{2}{|l|}{$\operatorname{Pr} 2 \mathrm{~S}\left(135^{\circ}-200^{\circ} \mathrm{E}\right)$} & \\
\hline Mean & & 7.11 & 9.27 & & \\
\hline \multirow[t]{3}{*}{ Standard } & & 0.864 & 0.638 & & \\
\hline & \multicolumn{5}{|c|}{ Meridional Transport $\left(10^{\circ} \mathrm{S}, 500-50 \mathrm{hPa}, 10^{10} \mathrm{~kg} \mathrm{~m} \mathrm{~s}{ }^{-1}\right)$} \\
\hline & $\operatorname{Tr} 1\left(40^{\circ} \mathrm{W}-30^{\circ} \mathrm{E}\right)$ & $\operatorname{Tr} 2\left(30^{\circ}-135^{\circ} \mathrm{E}\right)$ & $\operatorname{Tr} 3\left(135^{\circ}-170^{\circ} \mathrm{E}\right)$ & $\operatorname{Tr} 4\left(180^{\circ}-120^{\circ} \mathrm{W}\right)$ & $\operatorname{Tr} 5\left(120^{\circ}-60^{\circ} \mathrm{W}\right)$ \\
\hline Mean & -2.67 & -9.46 & -2.14 & 2.53 & -3.27 \\
\hline \multirow[t]{3}{*}{ Standard } & 0.776 & 0.857 & 1.12 & 1.30 & 1.60 \\
\hline & \multicolumn{5}{|c|}{ Vertical Transport $\left(20^{\circ}-40^{\circ} \mathrm{N}\right)$} \\
\hline & Tw1N $\left(10^{\circ}-40^{\circ} \mathrm{E}\right)$ & & & Tw2N $\left(140^{\circ}-120^{\circ} \mathrm{W}\right)$ & Tw3N $\left(30^{\circ}-10^{\circ} \mathrm{W}\right)$ \\
\hline Mean & -2.81 & & & -1.49 & -1.22 \\
\hline \multirow[t]{3}{*}{ Standard } & 0.281 & & & 0.148 & 0.173 \\
\hline & \multicolumn{5}{|c|}{ Vertical Transport $\left(20^{\circ}-40^{\circ} \mathrm{S}\right)$} \\
\hline & Tw1S $\left(30^{\circ} \mathrm{W}-20^{\circ} \mathrm{E}\right)$ & Tw2S $\left(50^{\circ}-110^{\circ} \mathrm{E}\right)$ & Tw3S $\left(130^{\circ}-160^{\circ} \mathrm{E}\right)$ & Tw $4 \mathrm{~S}\left(105^{\circ}-70^{\circ} \mathrm{W}\right)$ & \\
\hline Mean & -2.29 & -4.44 & -1.57 & -1.41 & \\
\hline Standard & 0.555 & 0.486 & 0.494 & 0.584 & \\
\hline
\end{tabular}




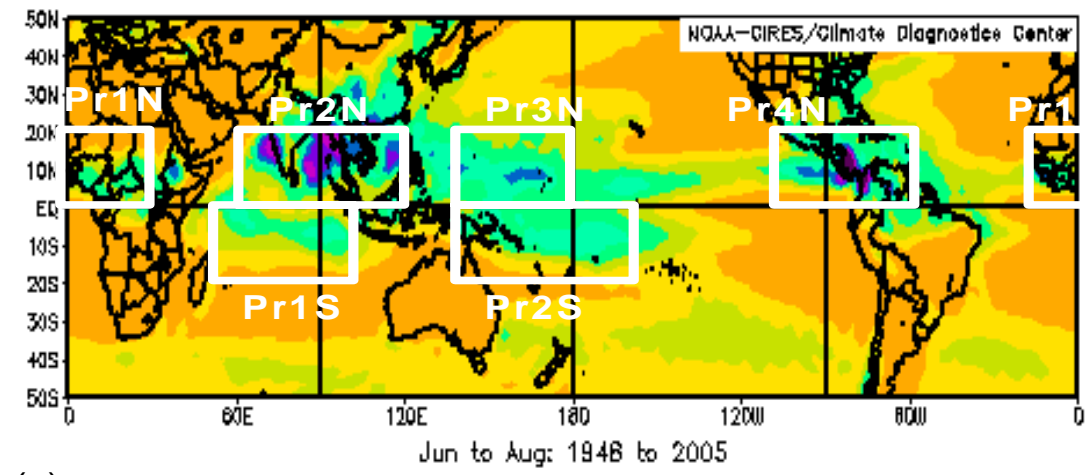

(a)

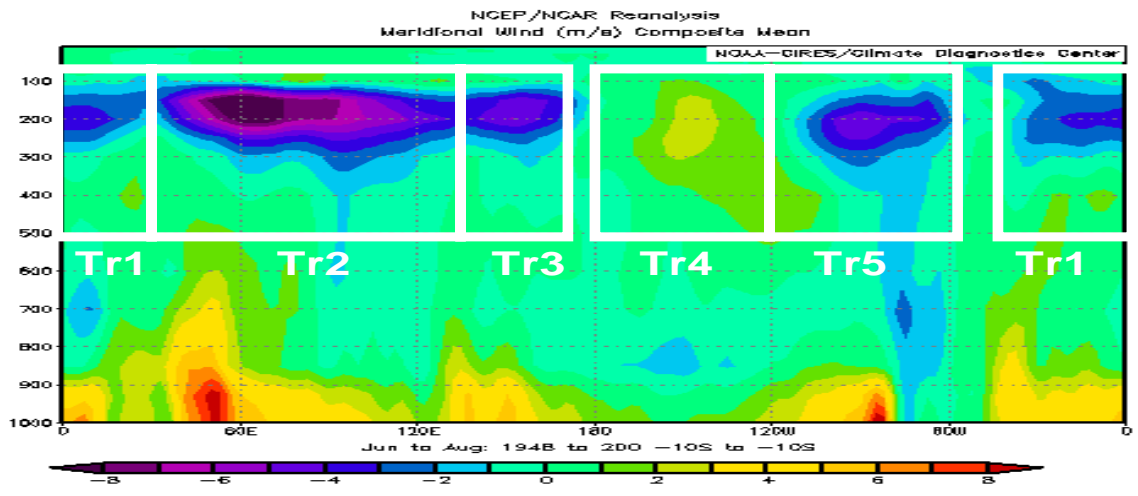

(b)

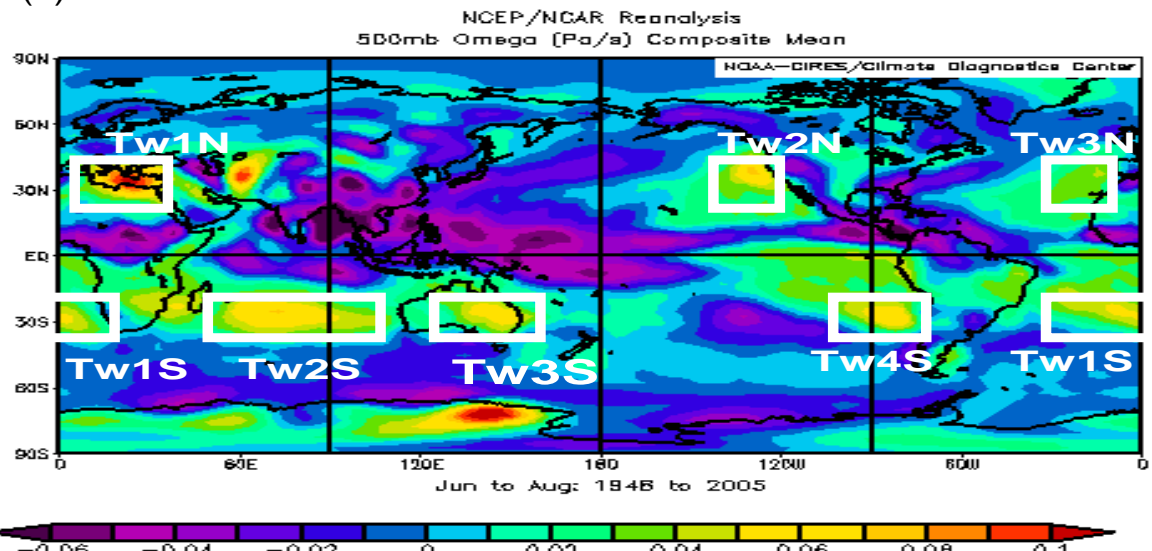

(c)

Fig. 7. (a) Mean conditions for JJA for 1948-2005, precipitation in $\mathrm{mm} \mathrm{d}^{-1}$, (b) and omega at $500 \mathrm{hPa}$ in $\mathrm{Pa} \mathrm{s}^{-1}$ north-south velocity at $10^{\circ} \mathrm{S}$ in $\mathrm{m} \mathrm{s}^{-1}$, (c) Note that omega is positive, velocity negative in the downwelling regions in. White boxes show the areas used in the correlation analysis for (a) precipitation, (b) north-south mass transport at $10^{\circ} \mathrm{S}$, and (c) vertical transports at $500 \mathrm{hPa}$.

which is also associated with the large subsidence over the Southern Indian Ocean (Tw2S). The other meridional transports $(\operatorname{Tr} 1, \operatorname{Tr} 3$ and $\operatorname{Tr} 5)$ have smaller mean values, comparable with each other. It is noteworthy that the precipitation occurs in four or five main regions, which correspond roughly with the four southward meridional transport regions visible in Figs. 6a and $7 \mathrm{~b}$, and the four subsidence regions centred on 
$30^{\circ} \mathrm{S}$. The fact that the largest members (Pr2N, Tr2 and Tw2S) appear to correspond with each other and form a dynamical group suggests that the same also applies to the others, though as shown below the real picture is more complex. For each of these regions, the upper tropospheric southward transport exceeds the transport sinking in the corresponding subsidence region, so that much of this southward transport must go elsewhere. For each case there are two possibilities (apart from subsidence) for this transport: that it continues southward through the mid-latitude baroclinic eddy field, or that it becomes part of the subtropical jet stream centred near $30^{\circ} \mathrm{S}$, shown in Fig. $6 \mathrm{~b}$.

For most of the variables listed in Table 3, the standard deviation is much smaller than the mean, implying that the fluctuations are relatively small. Correlation coefficients between all these various quantities are shown in Table 4. We use these correlation coefficients to examine relationships between these variables, but it should be remembered that, because many of the variations are relatively small, these coefficients realistically represent marginal relationships resembling derivatives, rather than relationships over the whole range of magnitudes. Never-theless, these relationships are in the ranges of interest for the present climate. Rather surprisingly, the precipitation records Pr1N, Pr2N and Pr4N do not correlate well with their corresponding transports at 10S: Tr1, $\operatorname{Tr} 2$ and $\operatorname{Tr} 4$, with the exception being $\operatorname{Pr} 3 \mathrm{~N}$ and $\operatorname{Tr} 3$. There is, however, strong positive correlation ( 0.5 or more) between all the horizontal transports $\operatorname{Tr} 1, \operatorname{Tr} 2$, $\operatorname{Tr} 3$ and $\operatorname{Tr} 5$, and the vertical transports in their respective subsidence regions: Tw1S, Tw2S, Tw3S and Tw4S. This is consistent with the zonally averaged behaviour shown in Fig. 4. This suggests that the main body of the upper level air emanating from the precipitation regions passes through the regions shown in Figs. 6a and 7b, but the perturbations associated with interannual variability do not. What is clear, however, is that the transports at $10^{\circ} \mathrm{S}$ are connected with the descent in their respective subsidence regions: $\operatorname{Tr} 1, \operatorname{Tr} 2, \operatorname{Tr} 3$ and $\operatorname{Tr} 5$ with Tw1S, Tw2S, Tw3S and Tw4S respectively: in each case, more transport implies more subsidence. Less convincingly, Tw1STw4S are also connected directly with the precipitation variables $\operatorname{Pr} 1 \mathrm{~N}-\mathrm{Pr} 4 \mathrm{~N}$ : more precipitation implies more subsidence.

A notable feature of the transports in the upper troposphere is the reversed branch of the Hadley circulation over the central Pacific: Tr4, in the longitude range $180^{\circ}-120^{\circ} \mathrm{W}$, at the downstream end of the subtropical jet stream. This is positively correlated with all the other branches, in that increased southward transport in them implies increased northward transport in $\operatorname{Tr} 4$. The transport of the southern subtropical jet stream (STJS) at $120^{\circ} \mathrm{E}$ is also included in the table, and this shows that this transport is connected to the precipitation in the African region Pr1N [as discussed in Baines (2005)], but not significantly to the others (this is partly attributable to the variance of Pr2N being small). However, the STJS transport is affected by the southward transports in the Hadley circulation branches, increasing with the transports in $\operatorname{Tr} 1, \operatorname{Tr} 2$ and $\operatorname{Tr} 5$ which may be regarded as upstream of it, and decreasing with $\operatorname{Tr} 3$ downstream. A stronger jet stream also implies a stronger northward reverse Hadley circulation, Tr4.

A final variable included in the table is the integrated north-south temperature difference across the main storm track, between $35^{\circ} \mathrm{S}$ and $55^{\circ} \mathrm{S}$, integrated from $1000 \mathrm{hPa}$ to $500 \mathrm{hPa}$, from $30^{\circ} \mathrm{E}$ to $90^{\circ} \mathrm{E}$. This was done to investigate possible connections between the Hadley circulation transports and the mid-latitude baroclinic eddy environment. There are indications of connections with $\operatorname{Tr} 1$ and $\operatorname{Tr} 3$, and with Tw3S, but these connections are not strong.

A schematic diagram illustrating some of the connections described is shown in Fig. 8. This shows a plan view of the surface of the Earth with the same projection (cylindrical equidistant) as used in other figures including Fig. 7. The black bordered boxes denote the precipitation regions $\operatorname{Pr} 1 \mathrm{~N}-\mathrm{Pr} 4 \mathrm{~N}, \operatorname{Pr} 1 \mathrm{~S}$ and Pr2S, the green boxes the subsidence regions Tw1NTw3N, Tw1S-Tw4S, and the blue broad arrows denote the upper tropospheric mass transports $\operatorname{Tr} 1-\operatorname{Tr} 5$ across the respective longitude ranges marked by blue lines at $10^{\circ} \mathrm{S}$. The reversed branch of the Hadley circulation, $\operatorname{Tr} 4$, is shown in light blue, the others dark. As described above, the four dark blue arrows connect the four main precipitation regions north of the equator with the four main subsidence regions south of the equator, on a one-to-one basis, and represent four individual branches of the Hadley circulation for this season (JJA). Connections between variables implied by correlations greater (mostly) than 0.25 are indicated by red arrows when the receiving variable is subsidence (a Tw variable), and by an orange arrow when it is an upper tropospheric transport (a Tr variable). Not all such correlations are represented: only those where some direct causative effect may be expected are included, and the direction of the arrows is in that of expected cause $\rightarrow$ effect. In particular, since the reverse transport $\operatorname{Tr} 4$ is seen as a partial return flow of the southward transports $\operatorname{Tr} 1-3$ and $\operatorname{Tr} 5$ (and 


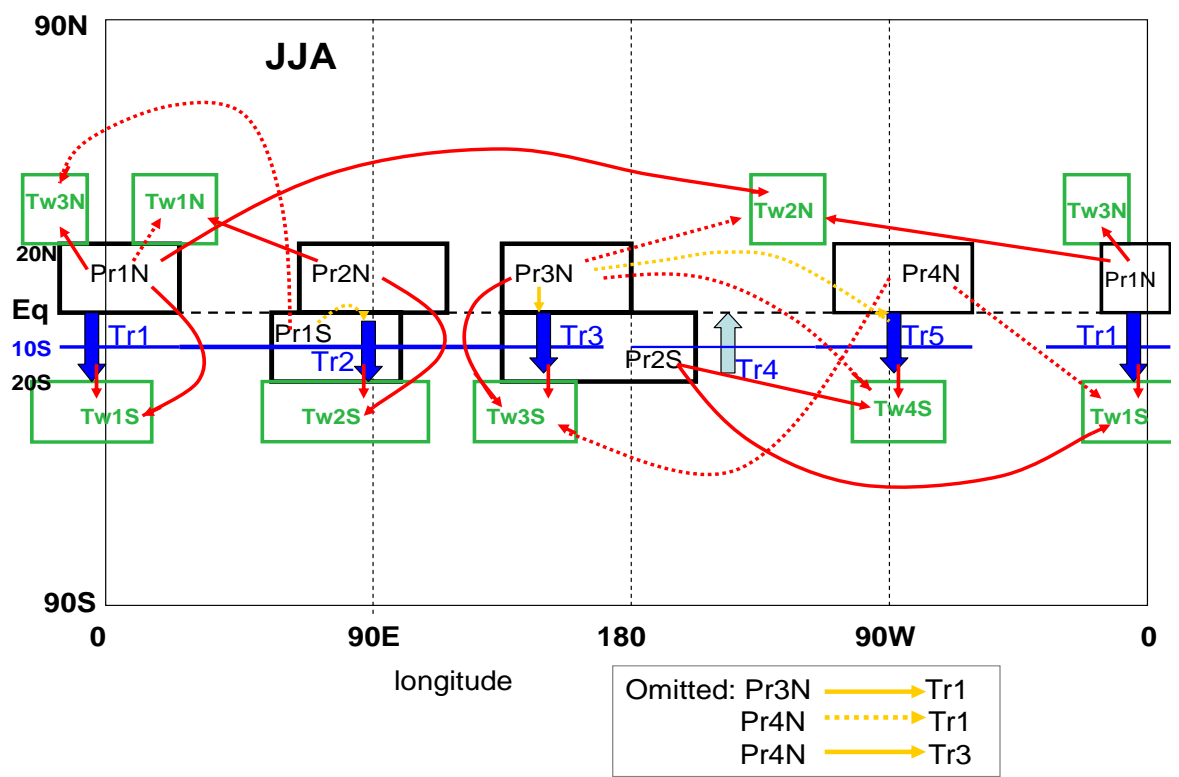

Fig. 8. Schematic diagram of the surface of the earth, showing the connections between some of the quantities listed in Table 4 for the season June-August. The black boxes denote the respective regions of large precipitation, the green boxes the regions of subsidence, and the blue broad arrows the upper tropospheric mass (and energy) transports. The horizontal blue lines at $10^{\circ} \mathrm{S}$ denote the ranges of longitude occupied by these fluxes. The connections between the precipitation in the black boxes and the subsidence in the green boxes, as described by the correlation coefficients in Table 4, are indicated by red arrows. If an increase in precipitation (in $\operatorname{Pr} 1 \mathrm{~N}$ say) causes an increase in downward subsidence (in Tw1S say), this is shown by a solid red arrow. If it corresponds to a decrease in downward transport (in Tw2N say), it is shown by a dotted red arrow. The influence of the precipitation regions on the meridional transports are shown by orange arrows: increased precipitation causing increased southward transport represented by a solid orange arrow, whereas if it causes decreased transport it is shown by a decrease. In order to avoid overly complicating the diagram, some of these connections are omitted but shown in a box beneath.

it is clearly related to $\operatorname{Tr} 2$ and $\operatorname{Tr} 3)$, its correlations with the other variables are omitted. Connections where the correlation is positive, in the sense that an increase of precipitation or transport causes an increase in transport or subsidence, are shown solid; where the correlation implies a decrease, the red arrows are shown dotted.

The diagram displays the following features. In terms of the mean values, the Hadley circulation appears to be primarily constituted of four distinct branches as noted above. In terms of the correlation coefficients, the short red arrows extending from the ends of dark blue arrows (representing Tr1-3 and Tr5) into the southern green boxes (Tr1S-Tr4S) indicate that these transports are directly connected with the subsidence regions on a one to one basis. The four northern precipitation regions $(\operatorname{Pr} 1-3 \mathrm{~N}, \operatorname{Pr} 5 \mathrm{~N})$ are also correlated with the four southern subsidence regions Tw1S-Tw4S (though the correlation between Pr4N and Tw4S is only 0.16 and is not shown). Note that this was not observed in the zonal means described in the previous section - the connection exists on an individual branch basis, but not collectively. Links between the precipitation regions and the upper tropospheric transports at $10^{\circ} \mathrm{S}$ are weak, with the exception of Pr3N and Tr3, and this constitutes a puzzle. Pr3N also has a negative effect on Tr5, as does Pr1S on Tr2. All the correlations between precipitation and subsidence regions with coefficients $>0.25$ are also shown. There are strong connections between precipitation and subsidence regions that give a "spaghetti diagram" character to the figure. These effects seem mostly to be real, though at present they are not well understood. 
(a)
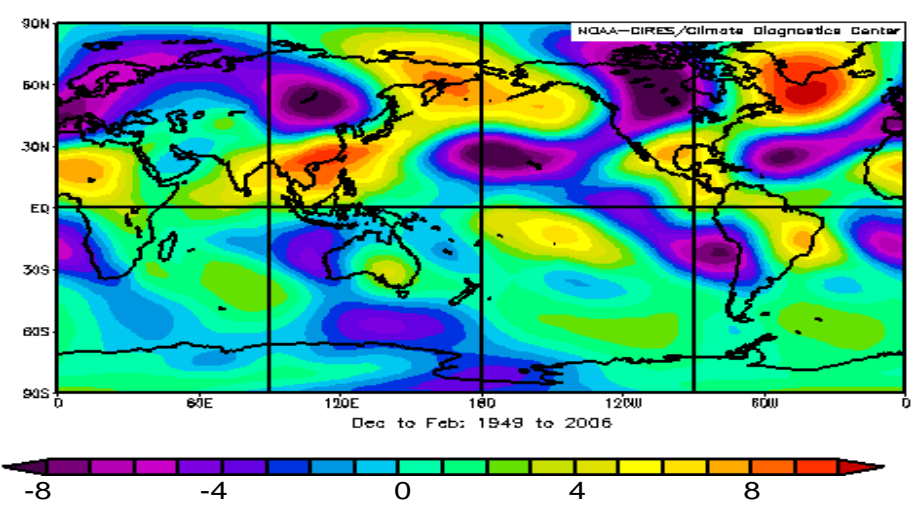

(b)

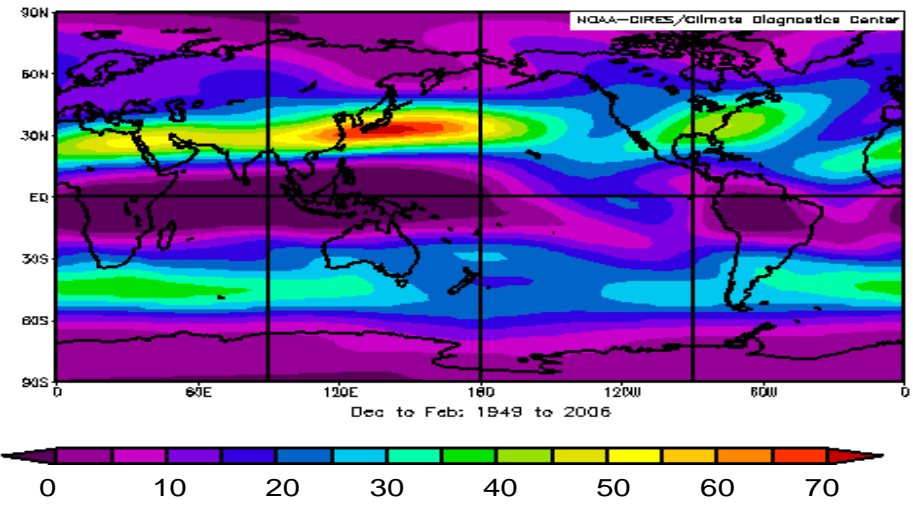

(c)

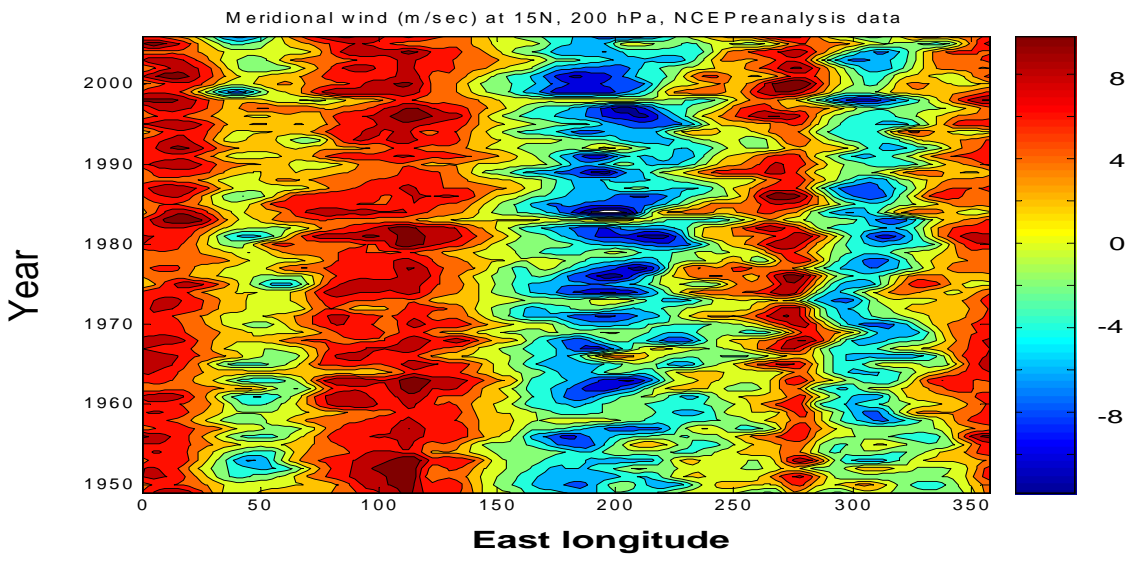

V $200 \mathrm{hPa}, 15 \mathrm{~N}, \mathrm{DJF}$

Fig. 9. The wind field at $200 \mathrm{hPa}$ for December-February. Velocities are in $\mathrm{m} \mathrm{s}^{-1}$. (a) Mean meridional wind for December-February over the period 1949-2006. (b) Mean zonal wind for June-August for 1949-2006. (c) Time series of the meridional wind at $200 \mathrm{hPa}$ at $15^{\circ} \mathrm{N}$ for December-February. Data from NCEP/NCAR reanalysis.

For December-February, the mean upper tropospheric flow at $200 \mathrm{hPa}$ is shown in Figs. 9a and 9b. The southern subtropical jet stream is absent for this season, and the northern one is prominent near $30^{\circ} \mathrm{N}$. Again, this jet stream grows in strength in regions where it is fed by northward flow from the tropics, and decreases in strength in the regions of reverse Hadley circulation, over the Pacific and Atlantic. Figure 9c shows the time series of northward motion at $200 \mathrm{hPa}$ at $15^{\circ} \mathrm{N}$, demonstrating that the three branches of the 
Hadley circulation and the two reversed branches for this season are all stable over the whole 58 years of reanalysis. Figure 10 shows the regions for precipitation, subsidence and the meridional transports, here taken at $15^{\circ} \mathrm{N}$, for the season December-February, as for Fig. 7 , together with the nomenclature for the variables. The corresponding mean values of these quantities for this season and their standard deviations, are given in Table 5, and the correlation coefficients are given in Table 6. The "spaghetti diagram" for these correlation values is shown in Fig. 11. The similarities and differences from June-August are instructive. The Hadley is dominated by the three main branches of the dominant cell. The main precipitation regions correspond to the three upper tropospheric transports, which are in turn have corresponding subsidence regions, but the connections between the precipitation and subsidence regions via correlations is less tidy. The transports are well correlated with their respective downstream subsidence regions, but seem to be poorly correlated with the precipitation regions, particularly the neighbouring ones.

\section{Conclusions and summary}

From an analysis of the mean conditions of the
NCEP/NCAR re-analysis data set, it is seen that the longitudinal structure of the main part of the Hadley circulation in the solsticial seasons of June-August and December-February exists as a discrete number of separate identifiable branches that stem from regions of concentrated tropical rainfall. These distinct branches are most clearly seen in the upper troposphere, where the poleward transport of mass and energy is concentrated in certain longitude bands that have remained stable throughout the re-analysis period of 1948-2005. There are four such branches for June-August, and three for December-February. In addition, there are reversed branches with equatorward upper level mass transport, which coincide with the termination regions of the subtropical jet streams: one for JJA centred near $150^{\circ} \mathrm{W}$, and two for DJF, centred near $170^{\circ} \mathrm{W}$ and $50^{\circ} \mathrm{W}$. The poleward branches become less distinct when they approach the latitude of $30^{\circ}$, and the poleward moving air has several possible destinations: sinking in the subsidence regions associated with the mid-latitude high pressure belt, continuing southward to higher latitudes, becoming part of the sub-tropical jet stream, and then returning equatorward as part of the upper level reverse Hadley circulation at the termination of the jet streams.

Table 5. As for Table 3, but for December to February.

\begin{tabular}{|c|c|c|c|c|c|c|}
\hline & \multicolumn{6}{|c|}{ Precipitation $\left(0^{\circ}-20^{\circ} \mathrm{N}, 10^{8} \mathrm{~kg} \mathrm{~m} \mathrm{~s} \mathrm{~s}^{-1}\right)$} \\
\hline & & $\operatorname{Pr} 1 \mathrm{~N}$ & $\operatorname{Pr} 2 \mathrm{~N}$ & $\operatorname{Pr} 3 \mathrm{~N}$ & & \\
\hline & & $80^{\circ}-135^{\circ} \mathrm{E}$ & $135^{\circ}-180^{\circ} \mathrm{E}$ & $180^{\circ}-110^{\circ} \mathrm{W}$ & & \\
\hline Mean & & 6.28 & 6.98 & 7.83 & & \\
\hline \multirow[t]{3}{*}{ Standard } & & 0.75 & 0.97 & 1.3 & & \\
\hline & \multicolumn{6}{|c|}{ Precipitation $\left(0^{\circ}-20^{\circ} \mathrm{S}, 10^{10} \mathrm{~kg} \mathrm{~m} \mathrm{~s}{ }^{-1}\right)$} \\
\hline & $\begin{array}{l}\operatorname{Pr} 1 \mathrm{~S} \\
\left(10^{\circ}-40^{\circ} \mathrm{E}\right)\end{array}$ & $\begin{array}{l}\operatorname{Pr} 2 \mathrm{~S} \\
\left(40^{\circ}-90^{\circ} \mathrm{E}\right)\end{array}$ & $\begin{array}{l}\text { Pr3S } \\
\left(110^{\circ}-150^{\circ} \mathrm{E}\right)\end{array}$ & $\begin{array}{l}\operatorname{Pr} 4 \mathrm{~S} \\
\left(150^{\circ} \mathrm{E}-160^{\circ} \mathrm{W}\right)\end{array}$ & & $\begin{array}{l}\text { Pr5S } \\
\left(80^{\circ}-40^{\circ} \mathrm{W}\right)\end{array}$ \\
\hline Mean & 3.83 & 7.89 & 6.77 & 9.61 & & 7.17 \\
\hline \multirow[t]{3}{*}{ Standard } & 0.32 & 0.96 & 0.94 & 1.03 & & 0.79 \\
\hline & \multicolumn{6}{|c|}{ Meridional Transport $\left(15^{\circ} \mathrm{N}, 500-50 \mathrm{hPa}, 10^{10} \mathrm{~kg} \mathrm{~m} \mathrm{~s}{ }^{-1}\right)$} \\
\hline & $\begin{array}{l}\operatorname{Tr} 1 \\
\left(30^{\circ} \mathrm{W}-50^{\circ} \mathrm{E}\right) \\
\end{array}$ & $\begin{array}{l}\operatorname{Tr} 2 \\
\left(60^{\circ}-150^{\circ} \mathrm{E}\right) \\
\end{array}$ & & $\begin{array}{l}\operatorname{Tr} 3 \\
\left(150^{\circ} \mathrm{E}-125^{\circ} \mathrm{W}\right)\end{array}$ & $\begin{array}{l}\operatorname{Tr} 4 \\
\left(125^{\circ}-75^{\circ} \mathrm{W}\right) \\
\end{array}$ & $\begin{array}{l}\operatorname{Tr} 5 \\
\left(75^{\circ}-30^{\circ} \mathrm{W}\right)\end{array}$ \\
\hline Mean & 9.52 & 10.42 & & -9.31 & 6.48 & -4.46 \\
\hline \multirow[t]{3}{*}{ Standard } & 1.65 & 2.15 & & 2.85 & 1.97 & 2.31 \\
\hline & \multicolumn{6}{|c|}{ Vertical Transport $\left(20^{\circ}-40^{\circ} \mathrm{N}, 10^{10} \mathrm{~kg} \mathrm{~m} \mathrm{~s} \mathrm{~s}^{-1}\right)$} \\
\hline & $\begin{array}{l}\mathrm{Tw} 1 \mathrm{~N} \\
\left(20^{\circ} \mathrm{W}-20^{\circ} \mathrm{E}\right)\end{array}$ & $\begin{array}{l}\text { Tw2N } \\
\left(110^{\circ}-145^{\circ} \mathrm{E}, 20^{\circ}-50^{\circ} \mathrm{N}\right)\end{array}$ & & & $\begin{array}{l}\text { Tw3N } \\
\left(135^{\circ}-100^{\circ} \mathrm{W}\right)\end{array}$ & \\
\hline Mean & -2.22 & -4.02 & & & -3.11 & \\
\hline \multirow[t]{3}{*}{ Standard } & 0.54 & 0.71 & & & 1.05 & \\
\hline & \multicolumn{6}{|c|}{ Vertical Transport $\left.\left(20^{\circ}-40^{\circ} \mathrm{S}, 10^{10} \mathrm{~kg} \mathrm{~m} \mathrm{~s} \mathrm{~s}^{-1}\right)\right)$} \\
\hline & $\begin{array}{l}\text { Tw1S } \\
\left(20^{\circ} \mathrm{W}-20^{\circ} \mathrm{E}\right) \\
\end{array}$ & $\begin{array}{l}\text { Tw2S } \\
\left(85^{\circ}-120^{\circ} \mathrm{E}\right)\end{array}$ & & & $\begin{array}{l}\text { Tw3S } \\
\left(110^{\circ}-70^{\circ} \mathrm{W}\right) \\
\end{array}$ & \\
\hline Mean & -2.21 & -1.68 & & & -2.36 & \\
\hline Standard & 0.35 & 0.36 & & & 0.37 & \\
\hline
\end{tabular}




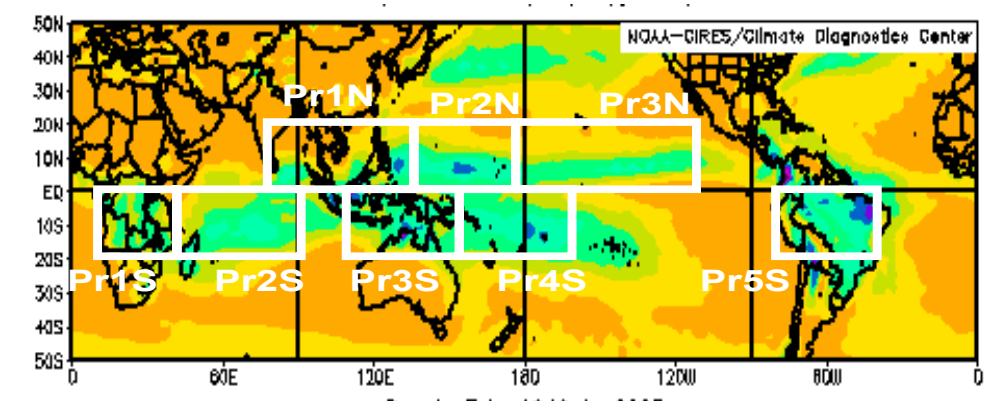

(a)

Dec to Feb: 1949 to 2005

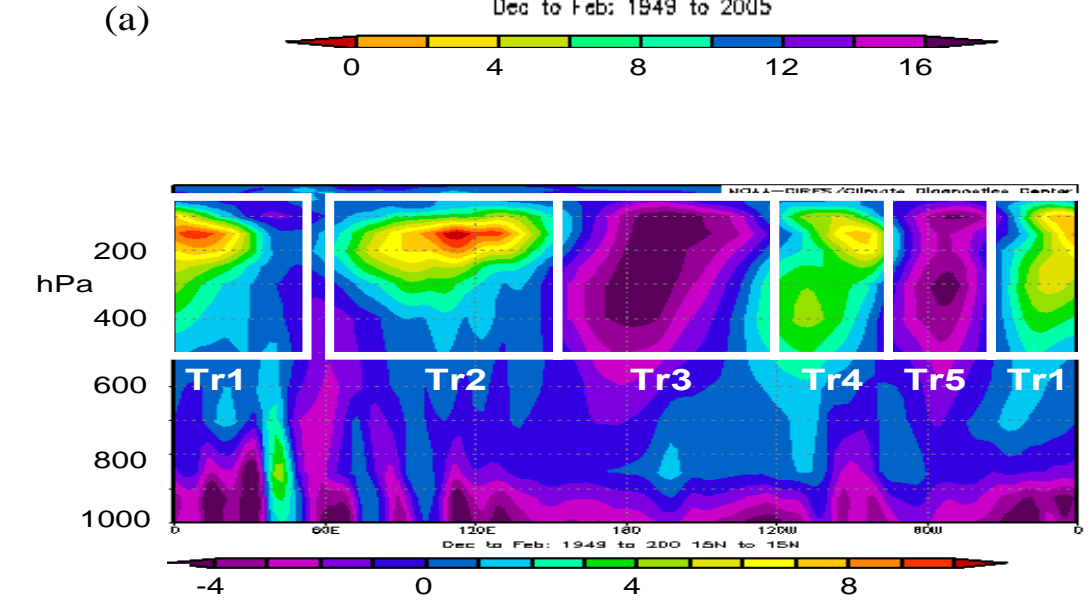

(b)

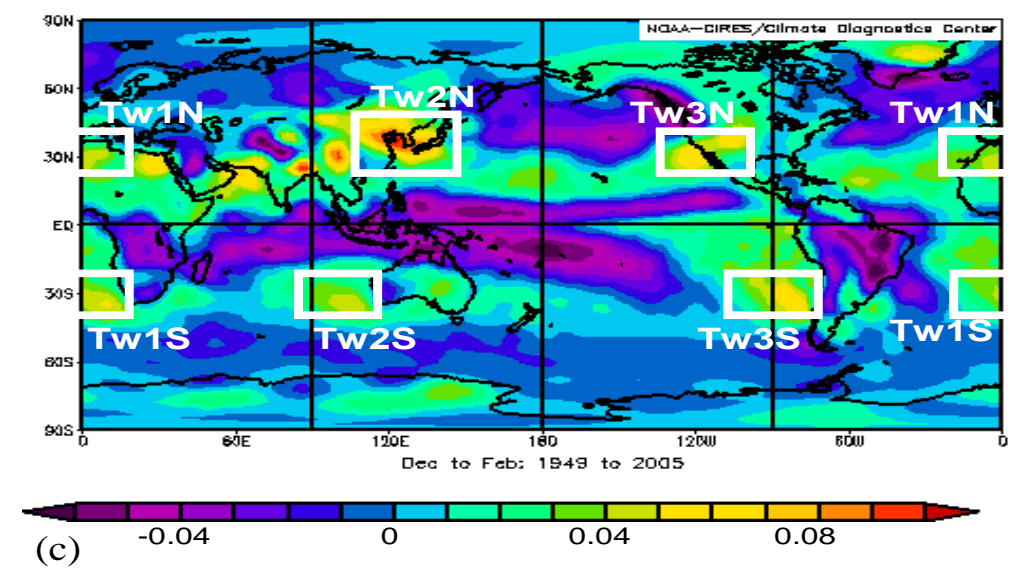

Fig. 10. As for Fig. 7, but for the season DJF.

The main results concerning the longitudinal structure are shown in Figs. 7 and 8 for JJA, and 10 and 11 for DJF. For JJA, there are four main northern precipitation regions shown in Fig. 7a, four main southward mass and heat transport regions in Fig. 7b, and four main southern regions of subsidence in the belt of subtropical highs. Mean magnitudes of the precipitation, southward transports and subsidence from Table 3 are compatible with these being four independent branches of the Hadley circulation. The correlation co- efficients, however, tell a slightly different story. The southward transports $(\operatorname{Tr} 1-3, \operatorname{Tr} 5)$ are connected to their respective downstream subsidence regions, and with one partial exception each of the four northern precipitation regions is connected to its corresponding southern subsidence region. This makes more sense than the picture from zonal means shown in Fig. 4, as it enables one to see how energy passes out of the tropics to higher latitudes. The northern precipitation regions are also positively related to subsidence in the 


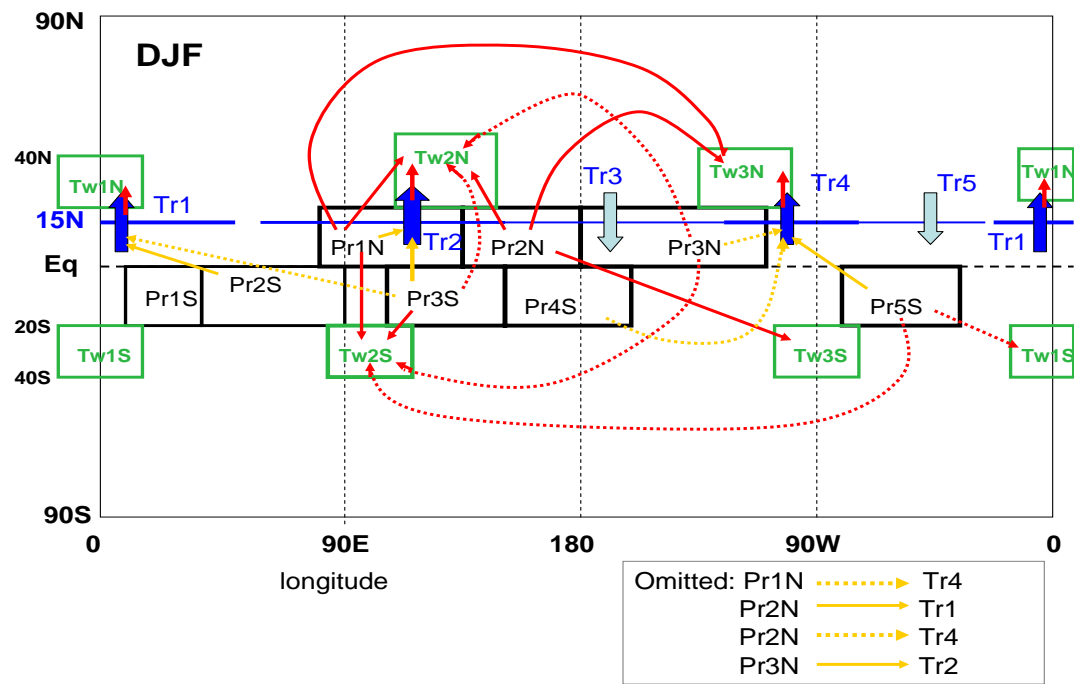

Fig. 11. As for Fig. 8, but for the season December-February.

northern regions to their west; this is consistent with models of the summer subtropical highs as being due to semi-stationary Rossby waves forced by the heat released in the precipitation regions (Rodwell and Hoskins, 1996, 2001; Chen et al., 2001; Chen, 2001). These connections are all illustrated in Fig. 8, but it is clear from this figure that there is also a number of significant connections for which there is at present no simple explanation. Some of the long-range connections shown may be via the subtropical jet streams, but this has yet to be investigated in detail.

The results for the season December-February show some differences, and are generally less tidy than those for JJA. The seasonally dominant southern part of the Hadley circulation now has three longitudinal branches of northward transport in the upper troposphere, with two reverse branches with southward motion located at the termination of the jet streams, near $170^{\circ} \mathrm{W}$ and $50^{\circ} \mathrm{W}$. There are also three northern subsidence regions, each of which is connected (via correlations) with its neighbouring northward transport region.

The approach of integrating various variables (precipitation, meridional transport, subsidence) over boxes where their values are large seems to be an appropriate way to proceed for the tropics, and provides useful information. However, there are other methods that can provide more comprehensive information such as empirical orthogonal functions, parcel trajectories and fluxes of moist static energy, which will help to explain some of the questions raised here.

\section{REFERENCES}

Baines, P. G., 2005: Long-term variations in winter rainfall of southwest Australia and the African monsoon. Aust. Met. Mag., 54, 91-102.

Baines, P. G., and C. Folland, 2006: Evidence for a rapid global climate shift across the late 1960s. Submitted to J. Clim..

Chen, P., 2001: Thermally forced stationary waves in a quasigeostrophic system. J. Atmos. Sci., 58, 15851594.

Chen, P., M. P. Hoerling, and R. M. Dole, 2001: The origin of the subtropical anticyclones. J. Atmos. Sci., 58, 1827-1835.

Peixoto, J. P., and A. H. Oort, 1992: Physics of Climate. American Institute of Physics, New York, 520pp.

Rodwell, M. J., and B. J. Hoskins, 1996: Monsoons and the dynamics of deserts. Quart. J. Roy. Meteor. Soc., 122, 1385-1404.

Rodwell, M. J., and B. J. Hoskins, 2001: Subtropical anticyclones and summer monsoons. J. Climate, 14, 3192-3211.

Trenberth, K. E., D. P. Stepaniak, and J. M. Caron, 2000: The global monsoon as seen through the divergent atmospheric circulation. J. Climate, 13, 3969-3993.

Trenberth, K. E., and D. P. Stepaniak, 2003a: Covariability of components of poleward atmospheric energy transports on seasonal and interannual time scales. $J$. Climate, 16, 3691-3705.

Trenberth, K. E., and D. P. Stepaniak, 2003b: Seamless poleward atmospheric energy transports and implications for the Hadley circulation. J. Climate, 16, 37063722 .

Webster, P. J. 2004: The elementary Hadley circulation. The Hadley Circulation: Present, Past and Future: An Introduction, Kluwer, 9-60.

Xie, S-P., 2004: The shape of continents, air-sea interaction, and the rising branch of the Hadley circulation. The Hadley Circulation: Present, Past and Future: An Introduction, Kluwer, 121-152. 


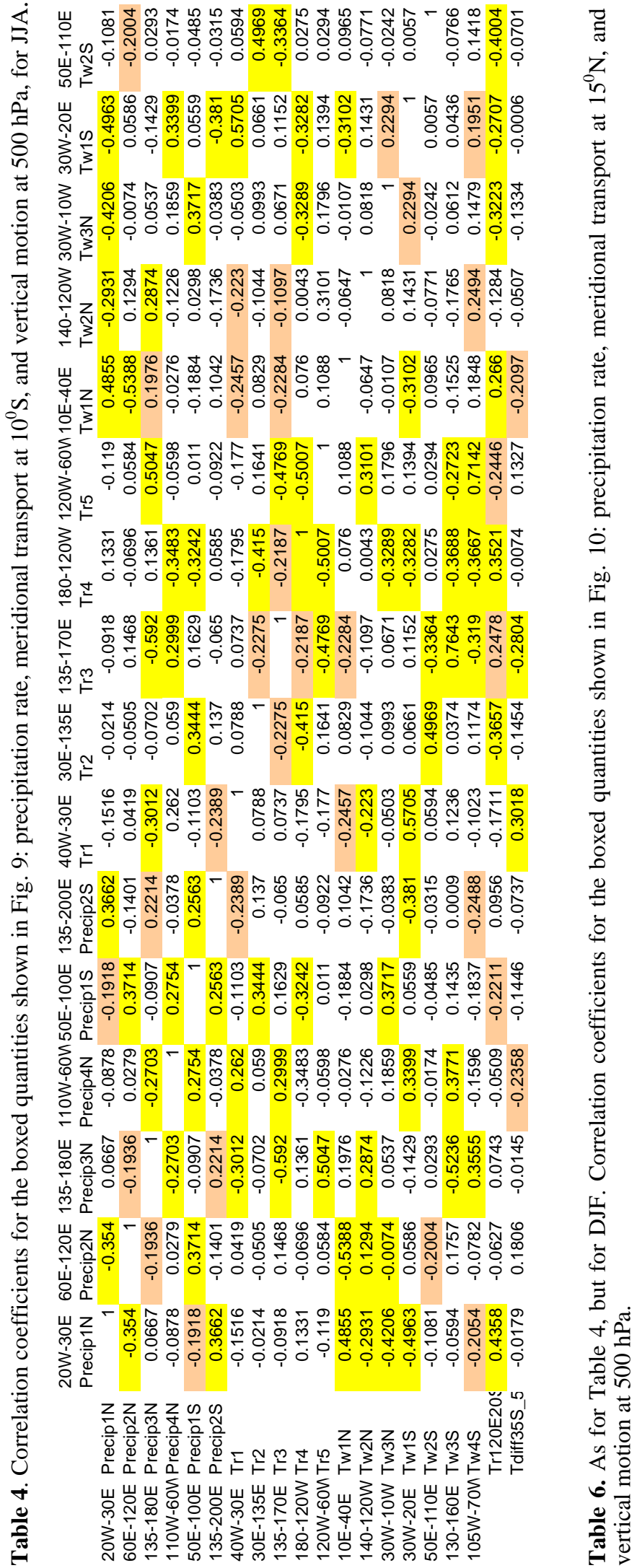

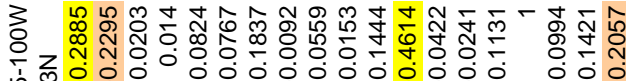
官 m

岁

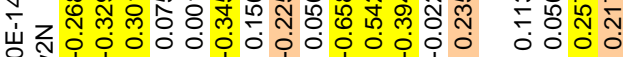
$\exists$

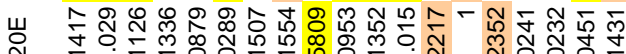

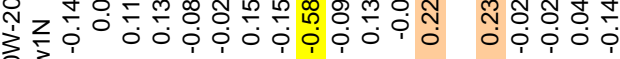
药

商员品

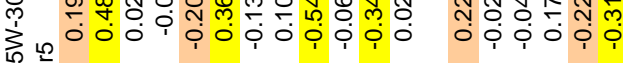
点里

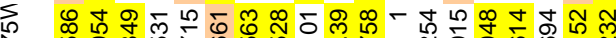

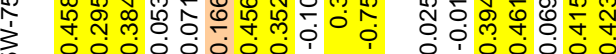
空

俩 峞 m 究馆

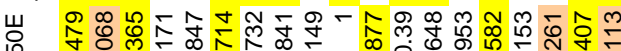

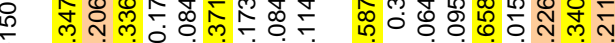

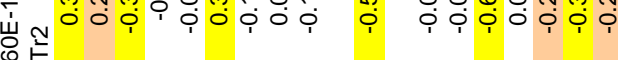

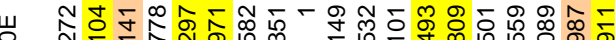

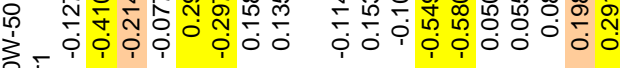
总芒

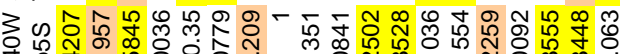

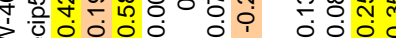

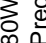

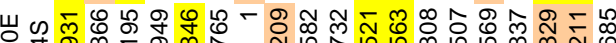

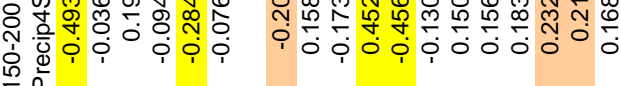

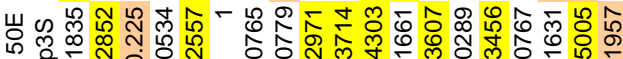

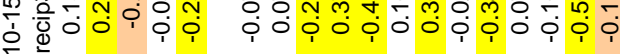

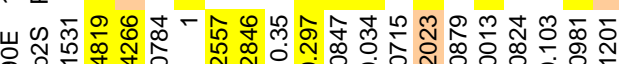

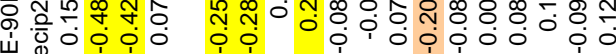
岁高

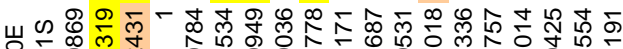

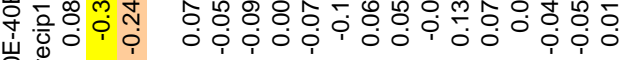
을

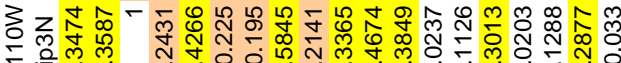

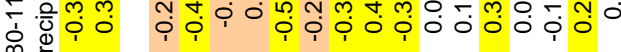

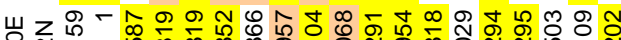

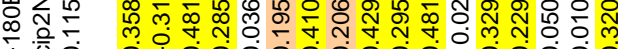

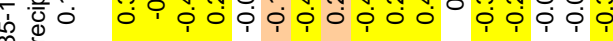
$\rightarrow$

嵌z $z^{-1}$

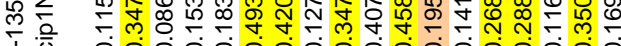

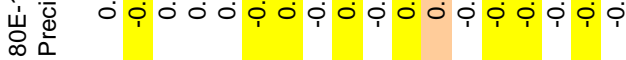

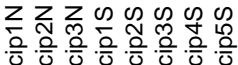

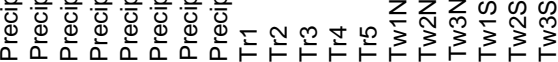

山㟧

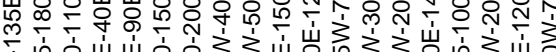

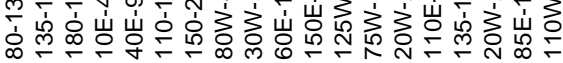

